\title{
PENGARUH TINGKAT PENGETAHUAN PERATURAN PAJAK E-COMMERCE DAN KESADARAN WAJIB PAJAK TERHADAP KEPATUHAN WAJIB PAJAK
}

\section{Ratih Juwita ${ }^{1}$, Alma Natasya ${ }^{2}$, Antoni ${ }^{3}$}

Universitas Gunadarma

Email: ratih_j@staff.gunadarma.ac.id ${ }^{1}$, almanatasya@student.gunadarma.ac.id ${ }^{2}$, antoni@staff.gunadarma.ac.id ${ }^{3}$

\section{Abstrak}

Latar belakang: Perkembangan e-commerce di Indonesia beberapa tahun ini mengalami peningkatan yang cukup pesat. Indonesia termasuk dalam 10 Negara dengan Presentase Penggunaan E-commerce Tertinggi di Dunia. Peningkatan jumlah pengguna e-commerce menimbulkan pertanyaan mengenai bagaimana peraturan perpajakan dalam mengantisipasi adanya penghasilan dari transaksi e-commerce.

Tujuan penelitian: This study aims to determine the effect of the level of knowledge of ecommerce tax regulations and awareness of taxpayers on taxpayer compliance on online shop business owners in Jabodetabek partially and simultaneously.

Metode penelitian: Metode analisis data yang digunakan adalah analisis deskriptif dengan menggunakan persamaan regresi linear berganda, koefisien determinasi $R^{\wedge} 2$, uji t dan uji $F$.

Hasil penelitian: menunjukkan bahwa tingkat pengetahuan peraturan pajak e-commerce berpengaruh secara parsial terhadap kepatuhan wajib pajak bahwa t Hitung $>\mathrm{t}$ Tabel $=2,445$ $>$ 1,664 dan untuk variabel kesadaran wajib pajak berpengaruh secara parsial terhadap kepatuhan wajib pajak bahwa t Hitung $>\mathrm{t}$ Tabel $=2,814>1,664$. Secara simultan variabel tingkat pengetahuan peraturan pajak e-commerce dan kesadaran wajib pajak berpengaruh terhadap kepatuhan wajib pajak. Hal tersebut dibuktikan dari nilai $\mathrm{F}$ hitung $>\mathrm{F}$ tabel $=$ $14,690>3,09$.

Kesimpulan: Tingkat Pengetahuan Peraturan Pajak E-commerce berpengaruh secara parsial terhadap Kepatuhan Wajib Pajak bahwa t Hitung > t Tabel $=2,445>1,664$

Kata kunci: Tingkat Pengetahuan Peraturan Pajak E-commerce, Kesadaran Wajib Pajak dan Kepatuhan Wajib Pajak

\section{Abstract}

Background: The development of e-commerce in Indonesia in recent years has increased quite rapidly. Indonesia is included in the 10 Countries with the Highest Percentage of Ecommerce Usage in the World (April 2021). The increase in the number of e-commerce users raises questions about how tax regulations anticipate income from e-commerce transactions.

The purpose of the study: to analyze the implementation of the preparation of cooperative financial statements based on the Regulation of the Minister of Cooperatives and SMEs No.13/Per/M.KUKM/IX/2015 concerning the accounting guidelines for cooperative savings and loans.

Research method: The data analysis method used is descriptive analysis using multiple linear regression equations, coefficient of determination $R^{\wedge} 2$, $t$-test and $f$-test.

The results of the study: shows that the level of knowledge of e-commerce tax regulations has a partial effect on taxpayer compliance that $t$ Count $>t$ Table $=2.445>1.664$ and for the taxpayer awareness variable it partially affects taxpayer compliance that $t$ Count $>t$ Table $=2.814>1.664$. Simultaneously, the variable level of knowledge of e-commerce tax regulations and taxpayer awareness has an effect on taxpayer compliance. This is evidenced by the calculated $F$ value $>F$ table $=14.690>3.09$.

Conclusion:Knowledge level of E-commerce Tax Regulations has a partial effect on Taxpayer Compliance that $t$ Count $>t$ Table $=2,445>1,664$

Keywords: Knowledge Level of E-commerce Tax Regulations, Taxpayer Awareness and Taxpayer Compliance

Diterima: 25-06-2021 Direvisi: 5-07-2021 Disetujui: 6-07-2021 
Pengaruh Tingkat Pengetahuan Peraturan Pajak E- e-ISSN: 2809-8862 Commerce dan Kesadaran Wajib Pajak terhadap p-ISSN: 2086-3306 Kepatuhan Wajib Pajak

\section{PENDAHULUAN}

Perkembangan e-commerce di Indonesia beberapa tahun ini mengalami peningkatan yang cukup pesat. Indonesia termasuk dalam 10 Negara dengan Presentase Penggunaan E-commerce Tertinggi di Dunia (April 2021). (Aini, n.d.)

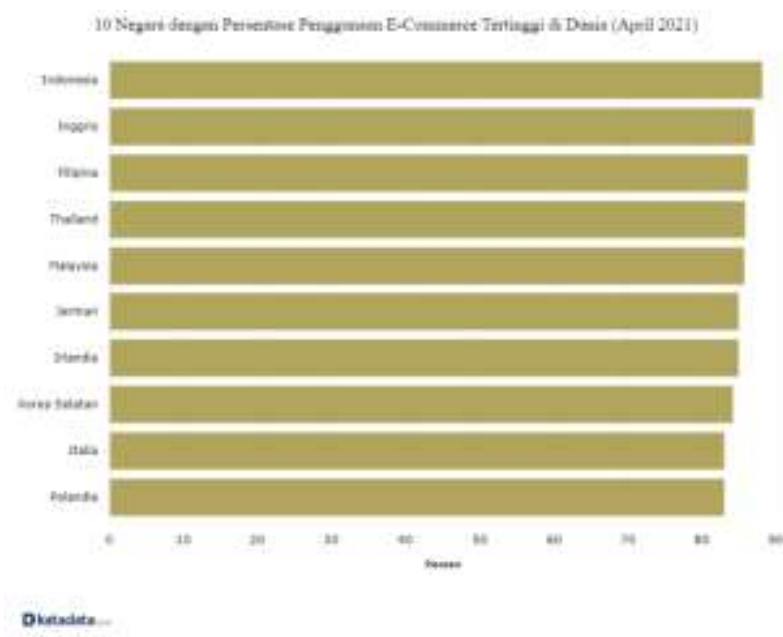

Gambar 1 Grafik 10 Negara dengan Presentase Penggunaan Ecommerce Tertinggi di Dunia (April 2021)

Sumber : We Are Spesial (21 April 2021)

Berdasarkan Gambar 1, sebanyak 88,1\% pengguna internet di Indonesia memakai layanan $e$-commerce untuk menjual atau membeli produk tertentu dalam beberapa bulan terakhir (Kabir, 2021). Presentase tersebut merupakan yang tertinggi di dunia dalam hasil survei We Are Social pada April 2021.

Peningkatan jumlah pengguna e-commerce menimbulkan pertanyaan mengenai bagaimana peraturan perpajakan dalam mengantisipasi adanya penghasilan dari transaksi e-commerce (Sari, 2018). Berdasarkan pertimbangan adanya model transaksi perdagangan melalui sistem elektronik (e-commerce), pemerintah memandang perlu lebih memudahkan pemenuhan kewajiban perpajakan bagi pelaku usaha perdagangan melalui sistem elektronik (e-commerce) sehingga para pelaku usaha dapat menjalankan hak dan kewajiban perpajakan dengan mudah sesuai model transaksi yang digunakan (Makarim, 2014). Peraturan Menteri Keuangan (PMK) Nomor 210/PMK.010/2018 tentang Perlakuan Perpajakan Atas Transaksi Perdagangan Melalui Sistem Elektronik (e-commerce) menimbang bahwa dengan meningkatnya transaksi perdagangan melalui sistem elektronik (e-commerce), perlu menjaga perlakuan yang setara antara perdagangan melalui sistem elektronik (e-commerce) dan perdagangan konvesional. Telah ditegaskan sebelumnya dalam Surat Edaran Direktur Jendral Pajak Nomor Se62/PJ/2013 tentang Penegasan Ketentuan Perpajakan Atas Transaksi E-commerce dan Surat Edaran Direktur Jendral Pajak Nomor Se-06/PJ/2015 tentang Pemotong dan/atau Pemungutan Pajak Penghasilan Atas Transaksi E-commerce dan ketentuan Pajak Penghasilan (PPh) yang diatur dalam Pemerintah No. 23 Tahun 2018, merupakan kebijakan pemerintah yang mengatur mengenai Pajak Penghasilan ( $\mathrm{PPh}$ ) atas penghasilan dari usaha yang diterima atau diperoleh Wajib Pajak yang memiliki peredaran bruto tertentu. Pengetahuan tentang pajak e-commerce sangat penting untuk para pemilik bisnis online shop (PRATIWI, 2020). 
Tingkat pengetahuan tentang pajak e-commerce dapat mempengaruhi apakah para pemilik bisnis online shop tersebut patuh akan kewajiban pajaknya atau tidak.(Limanita, 2019) Selain tingkat pengetahuan pajak e-commerce ada factor lain yang dapat mempengaruhi kepatuhan wajib pajak yaitu kesadaran wajib pajak (Noeranny \& Justinia Castellani, 2018). Kesadaran wajib pajak untuk membayar pajak tepat waktu akan mempengaruhi tinggi rendahnya terhadap kepatuhan wajib pajak (Salmah, 2018). Pemilik bisnis online shop yang memiliki kesadaran wajib pajak tinggi akan mengerti manfaat pajak untuk orang lain maupun diri sendiri. Dengan demikian pemilik bisnis online shop tersebut akan sukarela dan disiplin dalam membayar pajak (DINDA AYU NOVITA, 2020).

\section{METODE PENELITIAN}

Subjek yang menjadi dasar dalam penelitian ini adalah pemilik bisnis online shop di Jabodetabek. Yang dipengaruhi oleh variabel bebas berupa tingkat pengetahuan peraturan pajak e-commerce dan kesadaran wajib pajak (Zulvia, 2018). Adapun yang menjadi populasi dan sampel dalam penelitian ini adalah pemilik bisnis online shop yang berlokasi di Jabodetabek. Teknik dalam menentukan sampel yang digunakan dalam penelitian ini menggunakan teknik purposive sampel dengan pengambilan sampel tertentu dengan menggunakan kriteria tertentu (Nurdiani, 2014). Berdasarkan kriteria yang ditentukan dalam penelitian ini, yaitu:

1. Pemilik bisnis online shop yang berlokasi di Jabodetabek

2. Pemilik bisnis online shop yang telah beroperasi minimal 1 tahun

3. Pemilik bisnis online shop yang memiliki omzet tidak lebih dari Rp. 4.800.000.000 dalam satu tahun pajak.

Maka diperoleh sampel dalam penelitian ini yaitu 100 responden yang telah memenuhi kriteria yang ditentukan. Dalam penelitian ini digunakan perhitungan sampel rumus slovin (Yadewani \& Wijaya, 2017). Variabel independen yang digunakan dalam penelitian ini adalah:

1. Tingkat Pengetahuan Peraturan Pajak E-commerce

2. Kesadaran Wajib Pajak

Adapun model penelitian dalam penelitian ini adalah sebagai berikut:

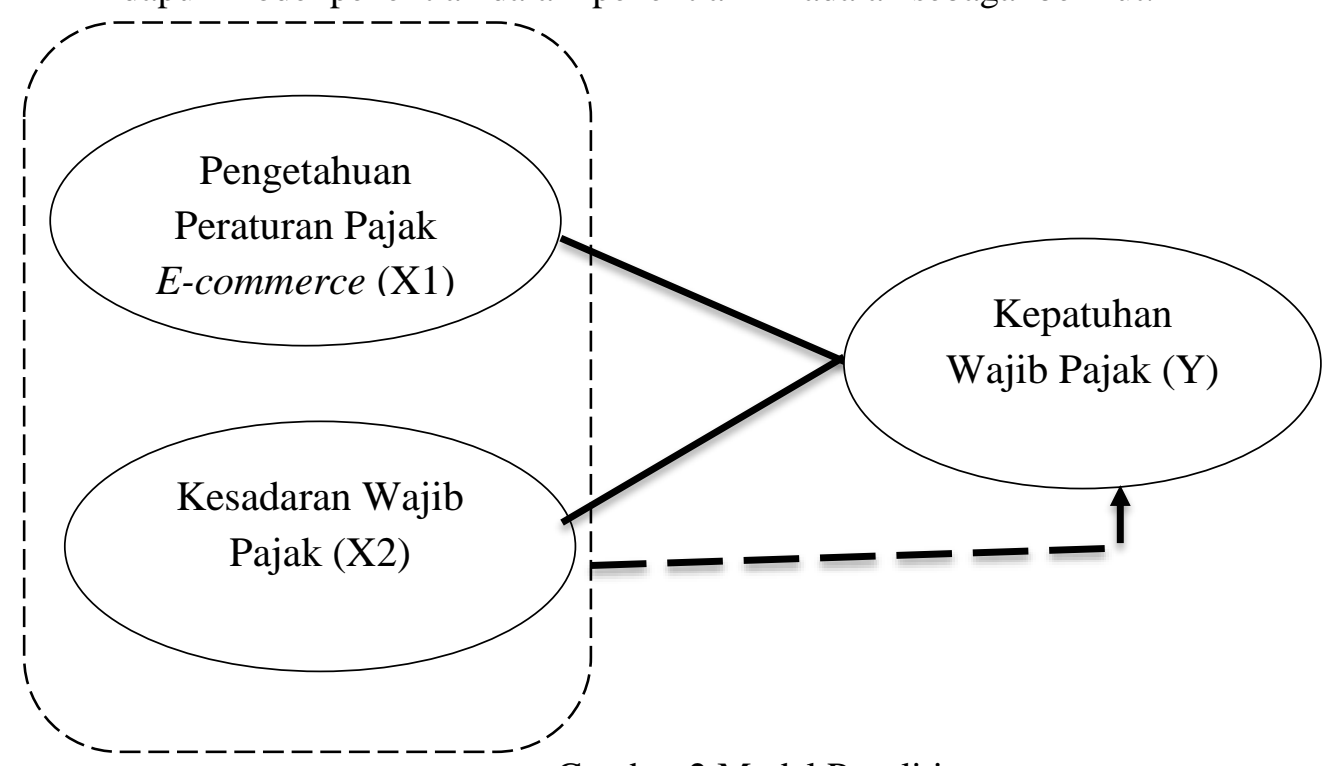

Gambar 2 Model Penelitian 
Adapun teknik pengumpulan datanya adalah studi pustaka dan kuesioner, dengan alat analisis yang digunakan berupa analisis deskriptif yang terdiri dari ;

1. Uji Validitas

2. Uji Reliabilitas

3. Uji Persamaan Regresi Linear Berganda

4. Uji Koefisien Determinasi

5. Uji t

6. Uji F

\section{Uji Validitas}

Menurut Sugiyono (2017:1210 Instrumen yang valid berarti alat ukur yang digunakan untuk mendapatkan data (mengukur) itu valid. Valid berarti instrument tersebut dapat digunakan untuk mengukur apa yang seharusnya diukur.

Kriteria pengujian adalah sebagai berikut ;

a) Jika $r$ hitung $>r$ tabel maka instrument atau item-item pertanyaan berkorelasi signifikan terhadap skor total (dinyatakan valid).

b) Jika $\mathrm{r}$ hitung $<\mathrm{r}$ tabel maka instrument atau item-item pertanyaan tidak berkorelasi signifikan terhadap skor total (dinyatakan tidak valid).

\section{Uji Reliabilitas}

Menurut Sugiyono (2017:121) Instrumen yang relibel berarti instrument yang bila terdapat kesamaan data dalam waktu yang berbeda, instrument yang relibel berarti instrument yang bila digunakan beberapa kali untuk mengukur objek yang sama akan menghasilkan data yang sama, uji reliabilitas kuesioner menggunakan prosedur yang sama dengan uji validitas. Uji reliabilitas adalah tingkat kestabilan suatu alat pengukur dalam mengukur suatu gejala atau kejadian. Semakin tinggi reliabilitas suatu alat ukur, semakin stabil pula alat pengukut tersebut.(Mohammad, 2018) Syarat uji reliabel yaitu :

a) Jika skor Cronbach's Alpha $>0,6$ maka variabel dinyatakan reliabel

b) Jika skor Cronbach's Alpha $<0,6$ maka variabel dinyatakan tidak reliabel

\section{Uji Persamaan Regresi Linear Berganda}

Persamaan regresi linear berganda adalah hubungan secara linear antara dua atau lebih variabel independen dengan variabel dependen. Analisis ini untuk mengetahui arah hubungan antara variabel independen dengan variabel dependen apakah masing-masing variabel independen berhubungan positif atau negative dan untuk memprediksi nilai dari variabel dependen apabila variabel independen mengalami kenaikan atau penurunan.(Weenas, 2013)

Persamaan regresi linier berganda sebagai berikut ;

$$
Y=a+b_{1} X_{1}+b_{2} X_{2}+\cdots+e
$$

Keterangan :

$$
\begin{array}{ll}
\mathrm{Y} & =\text { Kepatuhan } \\
\mathrm{a} & =\text { Konstanta } \\
\mathrm{b} 1, \mathrm{~b} 2 & =\text { Koefisien Regresi } \\
\mathrm{X} 1 & =\text { Pengetahuan Pajak } \\
\mathrm{X} 2 & =\text { Kesadaran Wajib Pajak } \\
\mathrm{e} & =\text { Residual error }
\end{array}
$$

Uji Koefisien Determinasi $R^{2}$ 
Koefisien determinasi $\left(R^{2}\right)$ pada umumnya digunakan untuk mengukur seberapa jauh kemampuan model dalam menerangkan variasi variabel dependen, nilai koefisien determinasi $\left(R^{2}\right)$ adalah antara nol dan satu, jika didapat $\left(R^{2}\right)$ yang kecil hal ini menunjukkan bahwa kemampuan variabel dependen sangat terbatas. Senaliknya jika didapat nilai $\left(R^{2}\right)$ yang besar atau mendekati satu maka hal ini menunjukkan bahwa variabel-variabel independen memberikan hampir sama semua informasi yang dibutuhkan untuk memprediksi atau menjelaskan variasi variabel dependen (Ghozali:2013).

Uji t

Uji ini digunakan untuk melakukan pengujian secara parsial berarti atau tidaknya hubungan variabel-variabel pengetahuan pajak (X1), kesadaran wajib pajak (X2) dengan variabel dependen kepatuhan wajib pajak (Y)

Uji F

Uji ini digunakan untuk mengetahui apakah variabel (X) secara bersama-sama berpengaruh secara signifikan terhadap variabel dependen $(\mathrm{Y})$.

\section{HASIL DAN PEMBAHASAN}

\section{Uji Validitas}

Tabel 1 Hasil Uji Validitas Tingkat Pengetahuan Peraturan Pajak E-commerce (X1)

\begin{tabular}{llll}
\hline Item & r Hitung & r Tabel & Keterangan \\
X1.1 & 0,486 & 0,195 & VALID \\
X1.2 & 0,604 & 0,195 & VALID \\
X1.3 & 0,644 & 0,195 & VALID \\
X1.4 & 0,642 & 0,195 & VALID \\
X1.5 & 0,629 & 0,195 & VALID \\
\hline
\end{tabular}

Sumber : SPSS 22

Tabel 2 Hasil Uji Validitas Kesadaran Wajib Pajak (X2)

\begin{tabular}{llll}
\hline Item & r Hitung & r Tabel & Keterangan \\
X2.1 & 0,697 & 0,195 & VALID \\
X2.1 & 0,687 & 0,195 & VALID \\
X2.3 & 0,772 & 0,195 & VALID \\
X2.4 & 0,746 & 0,195 & VALID \\
X2.5 & 0,704 & 0,195 & VALID \\
\hline
\end{tabular}

Sumber : SPSS 22

Tabel 3 Hasil Uji Validitas Kepatuhan Wajib Pajak (Y)

\begin{tabular}{cccc}
\hline Item & r Hitung & r Tabel & Keterangan \\
\hline Y.1 & 0,789 & 0,195 & VALID \\
\hline Y.2 & 0,915 & 0,195 & VALID \\
\hline Y.3 & 0,941 & 0,195 & VALID \\
\hline Y.4 & 0,856 & 0,195 & VALID \\
\hline Y.5 & 0,716 & 0,195 & VALID \\
\hline
\end{tabular}

Sumber : SPSS 22 
Pengaruh Tingkat Pengetahuan Peraturan Pajak E- e-ISSN: 2809-8862

Commerce dan Kesadaran Wajib Pajak terhadap p-ISSN: 2086-3306

Kepatuhan Wajib Pajak

\section{Uji Reliabilitas}

Tabel 4 Hasil Uji Reliabilitas Tingkat Pengetahuan Peraturan Pajak Ecommerce (X1)

Reliability Statistics

\begin{tabular}{|l|l|}
\hline $\begin{array}{l}\text { Cronbach's } \\
\text { Alpha }\end{array}$ & N of Items \\
\hline .844 & 5 \\
\hline
\end{tabular}

Sumber : SPSS 22

Tabel 5 Hasil Uji Reliabilitas Kesadaran Wajib Pajak (X2)

Reliability Statistics
\begin{tabular}{|l|l|}
\hline $\begin{array}{l}\text { Cronbach's } \\
\text { Alpha }\end{array}$ & N of Items \\
\hline .767 & 5 \\
\hline
\end{tabular}

Sumber : SPSS 22

Tabel 6 Hasil Uji Reliabilitas Kepatuhan Wajib Pajak (Y)

Reliability Statistics

\begin{tabular}{|l|l|}
\hline $\begin{array}{l}\text { Cronbach's } \\
\text { Alpha }\end{array}$ & N of Items \\
\hline .901 & 5 \\
\hline
\end{tabular}

Sumber : SPSS 22

Uji Persamaan Regresi Liniear Berganda

\begin{tabular}{|c|c|c|c|c|c|c|}
\hline \multicolumn{7}{|c|}{ Coefficients $^{\mathrm{a}}$} \\
\hline \multirow[b]{2}{*}{ Model } & & \multicolumn{2}{|c|}{ Unstandardized Coefficients } & \multirow{2}{*}{$\begin{array}{l}\text { Standardized } \\
\text { Coefficients } \\
\text { Beta }\end{array}$} & \multirow[b]{2}{*}{$\mathrm{t}$} & \multirow[b]{2}{*}{ Sig. } \\
\hline & & $\overline{\mathrm{B}}$ & Std. Error & & & \\
\hline \multirow[t]{3}{*}{1} & (Constant) & 4.487 & 2.690 & & 1.668 & .099 \\
\hline & $\begin{array}{l}\text { Pengetahuan } \\
\text { (X1) }\end{array}$ & .271 & .111 & .256 & 2.445 & .016 \\
\hline & $\begin{array}{l}\text { Kesadaran } \\
\text { (X2) }\end{array}$ & .394 & .140 & .295 & 2.814 & .006 \\
\hline
\end{tabular}

Tabel 7 Hasil Uji Regresi Linear Berganda

Sumber : SPSS 22 
Berdasarkan pada hasil analisis yang telah dilakukan tersebut, maka persamaan regresi yang telah terbentuk adalah sebagai berikut :

Variabel Tingkat Pengetahuan Peraturan Pajak E-commerce (X1) sebesar 0,271 mempunyai pengaruh positif terhadap variabel Kepatuhan Wajib Pajak (Y). dengan kata lain, jika Tingkat Pengetahuan Peraturan Pajak E-commerce (X1) ditingkatkan makan Kepatuhan Wajib Pajak (Y) pemilik bisnis online shop akan meningkat pula dengan nilai peningkatan 0,271 .

Variabel Kesadaran Wajib Pajak (X2) sebesar 0,394 mempunyai pengaruh positif terhadap variabel Kepatuhan Wajib Pajak (Y). dengan kata lain, jika Kesadaran Wajib Pajak (X2) ditingkatkan maka Kepatuhan Wajib Pajak (Y) pemilik bisnis online shop akan meningkat pula dengan nilai peningkatan sebesar 0,394.

Uji Koefisien Determinasi $\boldsymbol{R}^{2}$

Tabel 8 Hasil Uji Koefisien Determinasi

\begin{tabular}{lllll}
\hline \multicolumn{2}{l}{ Model Summary } & & & \\
Model & $\mathrm{R}$ & $\mathrm{R}$ Square & Adjusted R Square & $\begin{array}{l}\text { Std. Estimate } \\
\text { Est of the }\end{array}$ \\
\hline 1 & $.482^{\mathrm{a}}$ & .232 & .217 & 3.638 \\
\hline
\end{tabular}

a. Predictors: (Constant), kesadaran, pengetahuan

Sumber : SPSS 22

Berdasarkan analisis pada tabel 4.10 di atas, diperoleh asil $R^{2}$ (koefisien determinasi) sebesar 0,217 atau 217\%. Hal ini dapat diartikan bahwa Kepatuhan Wajib Pajak (Y) dipengaruhi oleh Tingkat Pengetahuan Peraturan Pajak E-commere (X1) dan Kesadaran Wajib Pajak (X2) sebesar 21,7\%. Dan sisanya sebesar 78,3\% dipengaruhi atau dijelaskan oleh variabel lain.

Uji t

Tabel 9 Hasil Uji t

\begin{tabular}{|c|c|c|c|c|c|c|}
\hline \multicolumn{7}{|c|}{ Coefficients $^{\mathbf{a}}$} \\
\hline \multirow[b]{3}{*}{ Model } & & \multirow{2}{*}{\multicolumn{2}{|c|}{ Unstandardized Coefficients }} & \multirow{2}{*}{$\begin{array}{l}\text { Standardized } \\
\text { Coefficients }\end{array}$} & \multirow[b]{3}{*}{$\mathrm{t}$} & \multirow[b]{3}{*}{ Sig. } \\
\hline & & & & & & \\
\hline & & $\mathrm{B}$ & Std. Error & Beta & & \\
\hline \multirow[t]{3}{*}{1} & (Constant) & 4.487 & 2.690 & & 1.668 & .099 \\
\hline & $\begin{array}{l}\text { Pengetahuan } \\
\text { (X1) }\end{array}$ & .271 & .111 & .256 & 2.445 & .016 \\
\hline & Kesadaran $(X$ & .394 & .140 & .295 & 2.814 & .006 \\
\hline
\end{tabular}

a. Dependent Variable: kepatuhan (Y)

Sumber : SPSS 22

Berdasarkan analisis pada tabel, diperoleh hasil sebagai berikut:

a. Uji Hipotesis Pengaruh Tingkat Pengetahuan Peraturan Pajak E-commerce Terhadap Kepatuhan Wajib Pajak

Berdasarkan hasil pengujian bahwa t Hitung $>\mathrm{t}$ Tabel $=2,445>1,664$, dengan nilai signifikan $0,016<0,05$. Maka hipotesis yang menyatakan bahwa "terdapat pengaruh tingkat pengetahuan peraturan pajak e-commerce terhadap kepatuhan wajib pajak" diterima. Pengetahuan peraturan pajak disini yaitu proses dimana wajib pajak mengetahui tentang perpajakan dan mengaplikasikan pengetahuan tersebut untuk 
Pengaruh Tingkat Pengetahuan Peraturan Pajak E- e-ISSN: 2809-8862 Commerce dan Kesadaran Wajib Pajak terhadap p-ISSN: 2086-3306 Kepatuhan Wajib Pajak

membayar pajak. Pengetahuan tersebut seperti memiliki Nomor Pokok Wajib Pajak (NPWP), pengetahuan serta pemahaman hak dan kewajiban sebagai wajib pajak.

b. Uji Hipotesis Pengaruh Kesadaran Wajib Pajak Terhadap Kepatuhan Wajib Pajak

Berdasarkan hasil pengujian bahwa t Hitung $>\mathrm{t}$ Tabel $=2,814>1,664$, dengan nilai signifikan $0,006<0,05$. Maka hipotesis yang menyatakan bahwa "terdapat pengaruh kesadaran wajib pajak terhadap kepatuhan wajib pajak" diterima. Kesadaran wajib pajak disini yaitu dimana wajib pajak memahami dan melaksanakan aturan perpajakan dengan benar dan sukarela. Kesadaran wajib pajak tersebut antara lain seperti mengetahui bahwa fungsi pajak untuk pembiayaan negara.(Prakoso et al., 2019)

Uji F

Tabel 10 Hasil Uji F

ANOVA $^{\mathrm{a}}$

\begin{tabular}{|ll|l|l|l|l|l|}
\hline Model & & Sum of Squares & df & Mean Square & F & Sig. \\
\hline 1 & Regression & 388.878 & 2 & 194.439 & 14.690 & $.000^{\mathrm{b}}$ \\
& Residual & 1283.872 & 97 & 13.236 & & \\
& Total & 1672.750 & 99 & & & \\
\hline
\end{tabular}

a. Dependent Variable: kepatuhan

b. Predictors: (Constant), kesadaran, pengetahuan

Sumber : SPSS 22

Berdasarkan analisis pada tabel 4.12, diperoleh $\mathrm{F}$ hitung $>\mathrm{F}$ tabel $=14,690>$ 3,09 , dengan nilai signifikan $0,000<0,05$. Jadi dapat disimpulkan bahwa variabel tingkat pengetahuan peraturan pajak e-commerce (X1), kesadaran wajib pajak (X2) berpengaruh bersama-sama atau simultan terhadap kepatuhan wajib pajak (Y).

\section{KESIMPULAN}

Berdasarkan data yang diolah, analisa dan hasil pembahasan yang dilakukan dalam penelitian ini, maka dapat disimpulkan bahwa tingkat Pengetahuan Peraturan Pajak $E$ commerce berpengaruh secara parsial terhadap Kepatuhan Wajib Pajak bahwa t Hitung > t Tabel $=2,445>1,664$. Kesadaran Wajib Pajak berpengaruh secara parsial terhadap Kepatuhan Wajib Pajak bahwa t Hitung $>\mathrm{t}$ Tabel $=2,814>1,664$, dimana dalam penelitian ini variabel Kesadaran Wajib Pajak lebih tinggi atau lebih berpengaruh terhadap Kepatuhan Wajib Pajak daripada variabel Tingkat Pengetahuan Peraturan Pajak E-commerce. Tingkat Pengetahuan Peraturan E-commerce dan Kesadaran Wajib Pajak secara bersama-sama atau simultan berpengaruh terhadap Kepatuhan Wajib Pajak. Bahwa $\mathrm{F}$ hitung $>\mathrm{F}$ tabel $=14,690>3,09$ dengan nilai signifikan $0,000<0,05$.

\section{BIBLIOGRAFI}

Aini, F. (n.d.). Pengaruh Perkembangan E-Commerce dan Infrastruktur Telekomunikasi Terhadap Pertumbuhan Ekonomi Indonesia Tahun2001-2018. Fakultas Ekonomi dan Bisnis uin jakarta.

DINDA AYU NOVITA, S. (2020). PENGARUH KESADARAN WAJIB PAJAK, KEPERCAYAAN PADA PEMERINTAH, DAN SANKSI PAJAK TERHADAP KEPATUHAN WAJIB PAJAK USAHA MIKRO, KECIL, DAN MENENGAH DI KECAMATAN PAKAL (Studi Pada UMKM Yang Ada Di Area Pondok Benowo Indah). Universitas Wijaya Putra.

Kabir, M. F. (2021). Adopsi E-commerce. 
Limanita, S. (2019). ANALISIS PERATURAN PAJAK E-COMMERCE, TARIF PAJAK ECOMMERCE, KESADARAN WAJIB PAJAK TERHADAP KEPATUHAN WAJIB PAJAK YANG MELAKUKAN USAHA DENGAN SISTEM E-COMMERCE. Sekolah Tinggi Ilmu Ekonomi Indonesia (STEI) Jakarta.

Makarim, E. (2014). Kerangka kebijakan dan reformasi hukum untuk kelancaran perdagangan secara elektronik (e-commerce) di Indonesia. Jurnal Hukum \& Pembangunan, 44(3), 314-337.

Mohammad, A. (2018). ANALISIS PENGUKURAN KINERJA DENGAN PENDEKATAN METODE BALANCED SCORECARD SEBAGAI UPAYA MENINGKATKAN KINERJA PERUSAHAAN (Studi Kasus: Titiktemu Creativehouse, Yogyakarta).

Noeranny, W., \& Justinia Castellani, S. E. (2018). Pengaruh Tingkat Pengetahuan Pelaku Bisnis E-Commerce Mengenai Peraturan Pajak Atas Transaksi ECommerce Terhadap Kepatuhan Wajib Pajak (Penelitian dilakukan pada Pemilik Bisnis E-Commerce di Kota Bandung). Perpustakaan Fakultas Ekonomi dan Bisnis Unpas Bandung.

Nurdiani, N. (2014). Teknik sampling snowball dalam penelitian lapangan. ComTech: Computer, Mathematics and Engineering Applications, 5(2), 1110-1118.

Prakoso, A., Wicaksono, G., Iswono, S., Puspita, Y., Bidhari, S. C., \& Kusumaningrum, N. D. (2019). Pengaruh Kesadaran dan Pengetahuan Wajib Pajak Terhadap Kepatuhan Wajib Pajak.

PRATIWI, I. W. (2020). ANALISIS TENTANG PEMAHAMAN PAJAK E-COMMERCE PADA PEMILIK BISNIS ONLINE SHOP DI SURABAYA. Universitas Bhayangkara.

Salmah, S. (2018). Pengaruh pengetahuan dan kesadaran wajib pajak terhadap kepatuhan wajib pajak dalam membayar Pajak Bumi dan Bangunan (PBB). Inventory: Jurnal Akuntansi, 2(1), 151-187.

Sari, R. P. (2018). Kebijakan perpajakan atas transaksi e-commerce. Akuntabel, 15(1), 67-72.

Weenas, J. R. S. (2013). Kualitas produk, harga, promosi dan kualitas pelayanan pengaruhnya terhadap keputusan pembelian Spring Bed Comforta. Jurnal EMBA: Jurnal Riset Ekonomi, Manajemen, Bisnis Dan Akuntansi, 1(4).

Yadewani, D., \& Wijaya, R. (2017). Pengaruh e-Commerce Terhadap Minat Berwirausaha. Jurnal RESTI (Rekayasa Sistem Dan Teknologi Informasi), 1(1), 6469.

Zulvia, D. (2018). PENGARUH PENERAPAN E-REGISTRATION, E-SPT DAN EPAYMENT TERHADAP TINGKAT KEPATUHAN WAJIB PAJAK DALAM MEMENUHI KEWAJIBAN PERPAJAKAN (PADA KATOR PELAYANAN PAJAK PRATAMA PADANG.

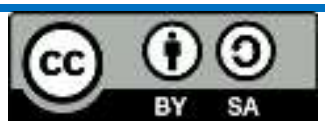

This work is licensed under a Creative Commons Attribution-ShareAlike 4.0 International License 